\title{
DEVELOPMENT OF THE HUMAN POTENTIAL OF UKRAINE IN THE CONTEXT OF THE POLISH EXPERIENCE
}

Formulation of the problem. The dialectics of human development in the minds of modern innovation economics is seen as a more important fact in the realization of the concept of development. Human potential is at the heart of the sustainable development system. The ultimate goal must be human development, and ecological growth is considered only as a means to achieve the goal.

In doing so, it is suggested that the degree of enrichment of the material and spiritual life of the person, enhancement of his quality, is

considered not a quantity of received goods, but a measure of human development. These applications are currently embedded in «new growth theories» (models of growth) and models that determine the impact of human potential on the GDP.

As transformation processes in transition economies are similar in nature, the study, adoption and adaptation of new best practices will be beneficial for Ukraine. Poland is an innovator of conceptual design, implementation of a new innovative management strategy - state anthropopolitics.

Analysis of the latest publications on the subject of the article. The definition of «human potential» is a rather complex economic category and is increasingly used by both domestic and foreign scientists. The category «human capital» is derived from the definitions: «labor», «labor resources», «labor potential», «human potential». Human capital in general should be considered as a set of natural abilities (health, creative inclination, etc.), as well as self-accumulated (acquired through life experience) and developed as a result of investing in education, training and rehabilitation.

The development of human potential in Ukraine, the analysis of its condition and the methods of measurement are relevant directions of scientific research of various scientific schools of Ukraine of socio-economic orientation. This is reflected in the scientific works of S.I. Pirozhkov and A.S. Vlasyuk, E.M. Libanova, E.A. Grishnova, L.A. Zayats, A.M. Kolot, V.V. Onnikienko, L.K. Semiv, T.M. Kiryan, A.I. Kurilo, L.S. Lisogor, V.P. Antonyuk, O.F. Novikova, L.L. Shamileva, N.A. Kizim, L.V. Shaulskaya, A.O. Revenko, L.I. Mikhailova, L.I. Bestelesnaya, V.V. Bliznyuk, Y.N. Pakhomova, I.K. Bondar, B.E. Kvasnyuk, A.M. Porochnik, I.F. Gnibidenko, D.P. Boginia, V. I. Kutsenko and others.
However, some aspects of the theoretical and methodological nature require the expansion of research on human development as a component of sustainable development, which has defined the purpose of the article.

Presentation of the main research material. The concept of sustainable development is embedded in the European Union's development model and is designed to meet the challenges of the present without compromising on the potential for future challenges.

It was destroyed by European countries in June 2001. and launched in March 2010, our new European strategy for sustainable development over the next 10 years - «Europe 2020: A Strategy for Reasonable, Sustainable and Comprehensive Growth» (Europe $2020 \mathrm{~A}$ strategy for smart, sustainable and inclusive growth) [1] aims to identify and implement measures for which EU countries are able to achieve a truly sustainable quality of life through the creation of sustainable communities capable of managing and effectively harnessing natural resources, enhancing natural resources.

Europe 2020 establishes three key facts that will help achieve the goal:

- smart growth: developing economics based on knowledge and innovation;

- sustainable growth: creating economics based on the sustainable use of resources, ecology and competition;

- full-inclusive growth: promoting population employment, achieving social and territorial development.

Five key indicators are identified by the performance indicators for the achievement of the set goals (Fig. 1).

Regulating the development of human potential in the EU remains the prerogative of national states. A single system for evaluating the implementation of the Strategy is not suitable because of the different levels of development of EU economists.

Each EU country has developed its own national goals for each direction, as well as specific measures at the national level that need to be taken to implement them.

In the current version of the Europe 2020 Strategy, the concept of human potential becomes the key to achieving the EU goal (Table 1).

«Ukraine 2020 Development Strategy» [6] is a modern basis document that defines Ukraine's sustaina- 
ble development policy as being ecologically sustainable and developing human potential [7]. Some economists have argued that «the core of the system of sus- tainable development is the system of unlocking quality resources - the most important of which is human potential».

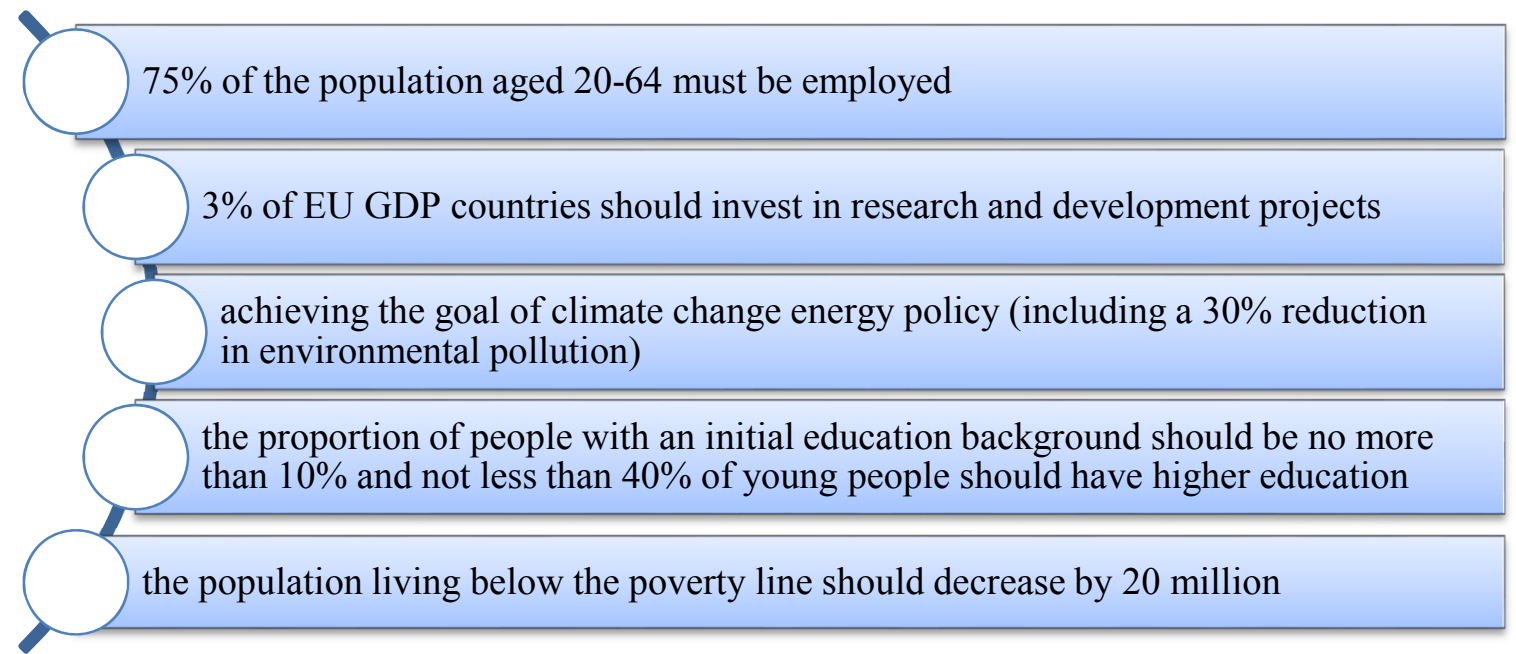

Fig. 1. Indicators of success in meeting Europe 2020 targets

Source: own processing.

Table 1 rational plans of the Government, strategic plans of the

Europe 2020 Strategy goals related to the quality of human potential

\begin{tabular}{|c|c|}
\hline Smart growth & Inclusive growth \\
\hline $\begin{array}{l}\text { Innovation. European Innovative } \\
\text { Union Key Initiative to improve } \\
\text { framework conditions and access } \\
\text { to funding for research, innova- } \\
\text { tion to strengthen innovation } \\
\text { chains and accelerate EU invest- } \\
\text { ment }\end{array}$ & $\begin{array}{l}\text { Employment and qualification. } \\
\text { European key initiative «Agenda } \\
\text { for job creation and skills» } \\
\text { (adopted by the European Com- } \\
\text { mission on } 10 \text { June 2016): Modern- } \\
\text { izing labor markets by increasing } \\
\text { labor mobility and developing } \\
\text { skills that foster successful em- } \\
\text { ployment }\end{array}$ \\
\hline $\begin{array}{l}\text { Education. European Movement } \\
\text { on Youth on the Move to improve } \\
\text { the functioning of education sys- } \\
\text { tems and enhance the international } \\
\text { attractiveness of European higher } \\
\text { education }\end{array}$ & $\begin{array}{l}\text { Combating poverty. European } \\
\text { Key Initiative «European Platform } \\
\text { for Poverty Reduction» (approved } \\
\text { on } 31 \text { March 2011): social and ter- } \\
\text { ritorial cohesion for people living } \\
\text { in poverty or excluded from soci- } \\
\text { ety, they lived decently and were } \\
\text { active members of society }\end{array}$ \\
\hline
\end{tabular}

Source: own processing.

One of the more ambitious strategic objectives of the Strategy is «... the introduction of European standards of living in Ukraine and Ukraine's entry into the world's leading positions» [6]. Further revising the Ukraine 2020 Strategy would have a paradigm of human-centrism, which implies a policy and practice, which requires a working person to feel foreign and socially protected.

The development of human resources is considered to be the ultimate result of the effective operation of the Government in the midst of the Government's 2020 priority plan [8]. It is this document that defines the main goals and directions of the Government's activities in 2017-2020, which are its budget planning, annual opeministries and other documents, focusing on the government.

Key metrics for achieving your 2020 goal defined by:

human development index - ranked in the top 50 countries;

mortality rate $-10 \%$ reduction;

the poverty rate (by EU method) $-15 \%$.

Unfortunately, experts' disappointing forecasts about Ukraine's place in the Human Development Index were unfortunately justified. According to the human development index in international comparisons, Ukraine is permanently moving from a group of countries with a high level of human development to a group of countries with an average level of its development and vice versa. During 1992-1999 Ukraine has consistently lost its position on the human development index, but the rate of decline of this indicator has been consistently reduced. This is primarily due to the deep transformation processes in all spheres of society, with economic stagnation, which resulted in a more than twofold decrease in GDP per capita, in a sharp and longterm deterioration of living conditions of people, which led to a significant reduction in life expectancy, which led to a decrease in the index human development in Ukraine and the corresponding deterioration in the country's rating

If in 1992 our country was in a fairly high rating position - 45th, then by 1995 it had sharply moved to 102 nd, and in 2000 - it was already 78th.

Although Ukraine's position in the country index has been slowly increasing since 2001 (from 80 in 2001 and 78 in 2003 to 77 and 76 in 2005-2006, respectively), in the 2009 report, Ukraine has taken into account the 
world financial crisis, which was only 85 th place, in 2018 Ukraine went down even lower and took 88th place. Ukraine's western neighbors - Poland, Slovakia and Hungary - ranked 33rd, 38th and 45th, respectively.

On the path of Ukraine to European integration, Poland has been considered as a major partner in recent years, which is explained by the desire of Polish busi- ness to expand in the Ukrainian market. Let us evaluate the factors that affect the human development of the two countries.

Therefore, the quality and level of human development are significantly influenced by the incomes of the population, which are definitely determined by the economic dynamics (Fig. 2).

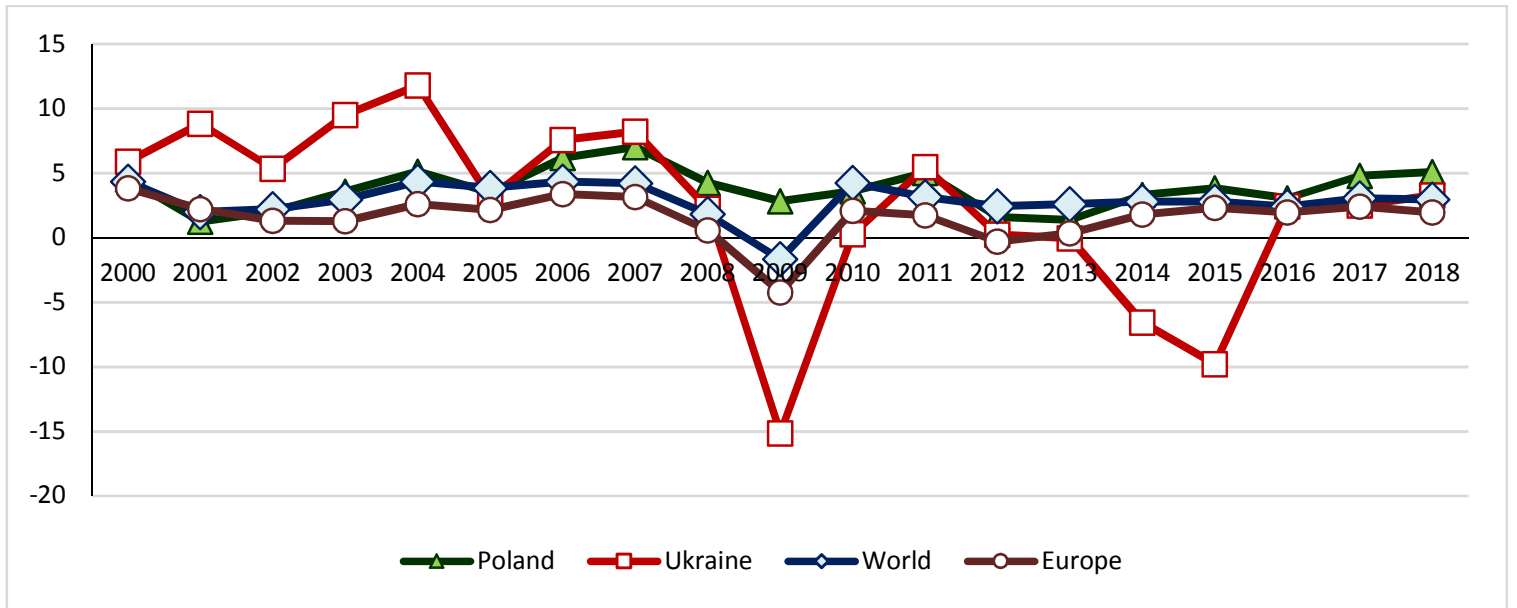

Fig. 2. Growth rates of real GDP of Poland and Ukraine in 2000-2018, \% compared to the previous year

Source: own processing.

According to Fig. 2 shows that since the beginning of the millennium Poland's GDP growth rates have been ahead of the GDP growth rates of the European countries, which is largely explained by the crisis in some countries (Italy, Portugal, Greece, etc.) due to the crisis, having a negative impact on European ecological dynamics in general.

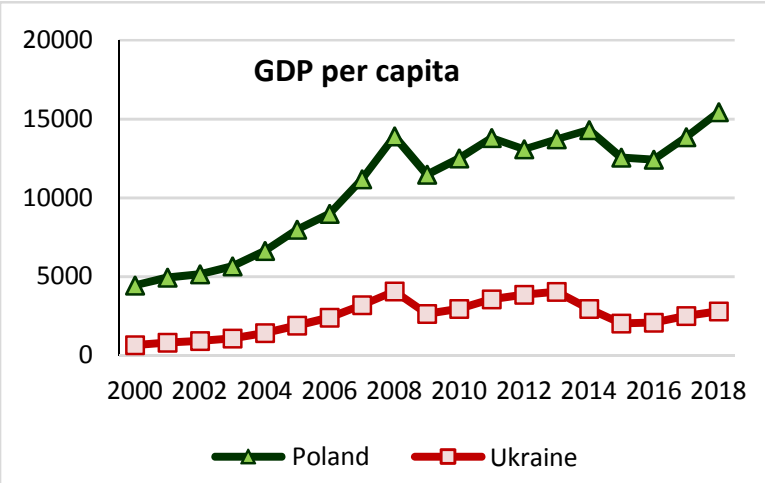

Fig. 3. GDP per capita and per capita employment in Poland and Ukraine in 2000-2018, USD USA
The stable economic dynamics of Poland also ensured an accelerated growth of the population (gross domestic product per capita). Somewhat different is the situation in the case of labor productivity analysis - the gross domestic product produced per employee is taken into account, given the purchasing power parity (Fig. 3).

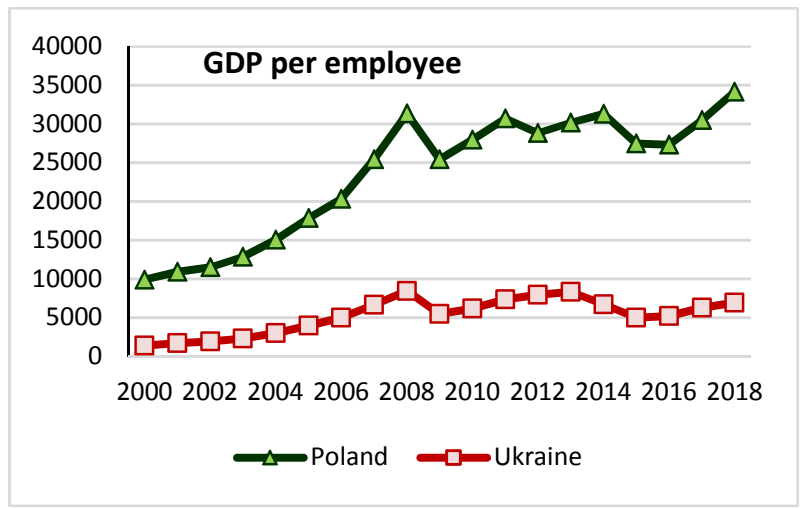

Source: own processing

In the post-crisis period in Poland, the growth of gross domestic product by one occupied somewhat decreased (in particular as a result of migration processes), however, the positive growing dynamics still persist. As far as Ukraine is concerned, the country's overall positive growth trend and periodic GDP per capita and productivity gains may not be sustained and may not be reflected in the country's overall performance.
Gross domestic product, in essence, is the sum of value added created, and is usually the main source of resources for wages and salaries received through wages and salaries. For the estimation of the real well-being of the population (on which the strengthening of the human potential depends) the real level of wages (that is, the nominal volumes weighted on the inflation index in the country) is crucial (Fig. 4). 

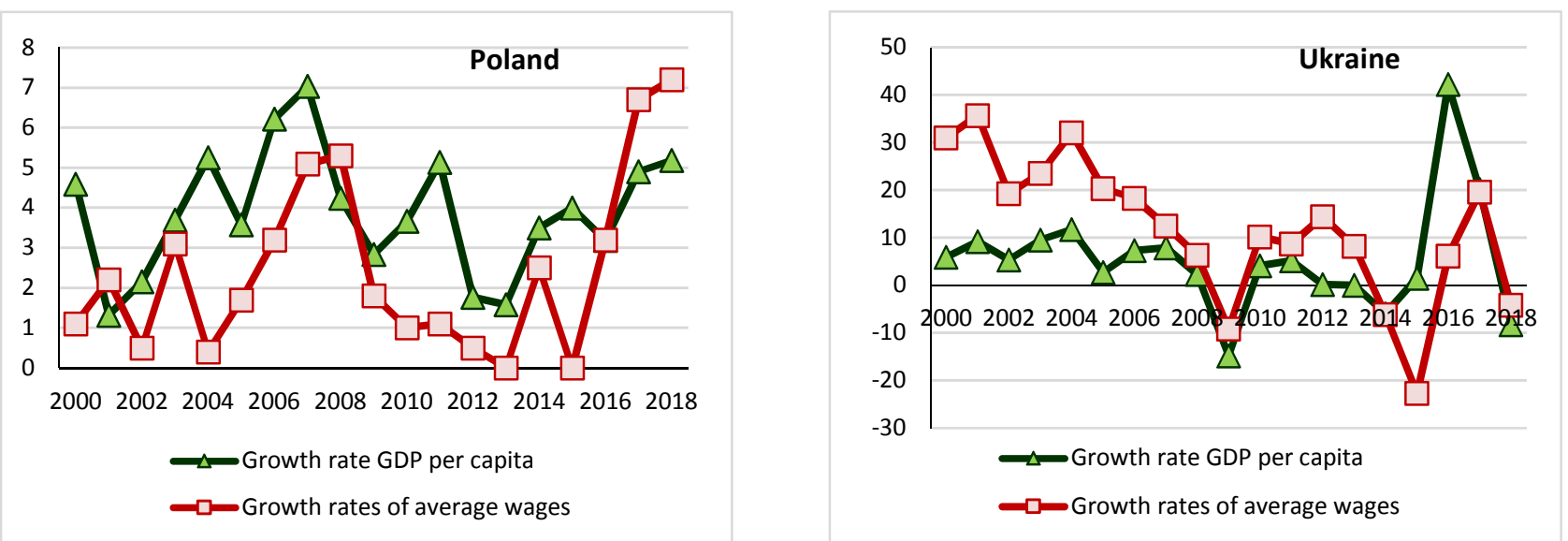

Fig. 4. GDP per capita dynamics and real wages in Poland and Ukraine in $\mathbf{2 0 0 0 - 2 0 1 8 , \%}$ to previous year

Source: own processing.

In Poland, the growth of real average wage is mainly driven by the growth of GDP per capita, with the dynamics of GDP per capita appearing even ahead. Given the low inflation, on the one hand, it has to do with export policy and strengthening the competitive position of Polish producers in foreign markets, and other services.

The other situation was observed in Ukraine - there are no significant relationships between the two indicators, but there are significant «differences» in the pace of wage growth (at higher sustainability of GDP dynamics). This specificity is periodically criticized by international financial institutions for its alleged inflationary potential. However, this is not borne out by the statistical observations that the effect of wages on inflation is negligible. More than that, excessive wage restraints in
2014-2016 only exacerbated and deepened the crisis crises (sharp deterioration of the real sector indicators) in Ukraine. In addition, the domestic dynamics of both GDP and real wages are excessively volatile, including. as a result, the worsening of the dynamics of the dynamics was accompanied by both inflationary and devaluation shocks.

Certain reserves of human resources improvement, primarily due to wage increases, are linked to the "modernization" of the economic structure: the highest level of wages in the service sector, the average level in the industry, and the lower level in the agricultural sector. At the same time, the attractive economic structure is an important factor in the inflow of human potential (Fig. 5).

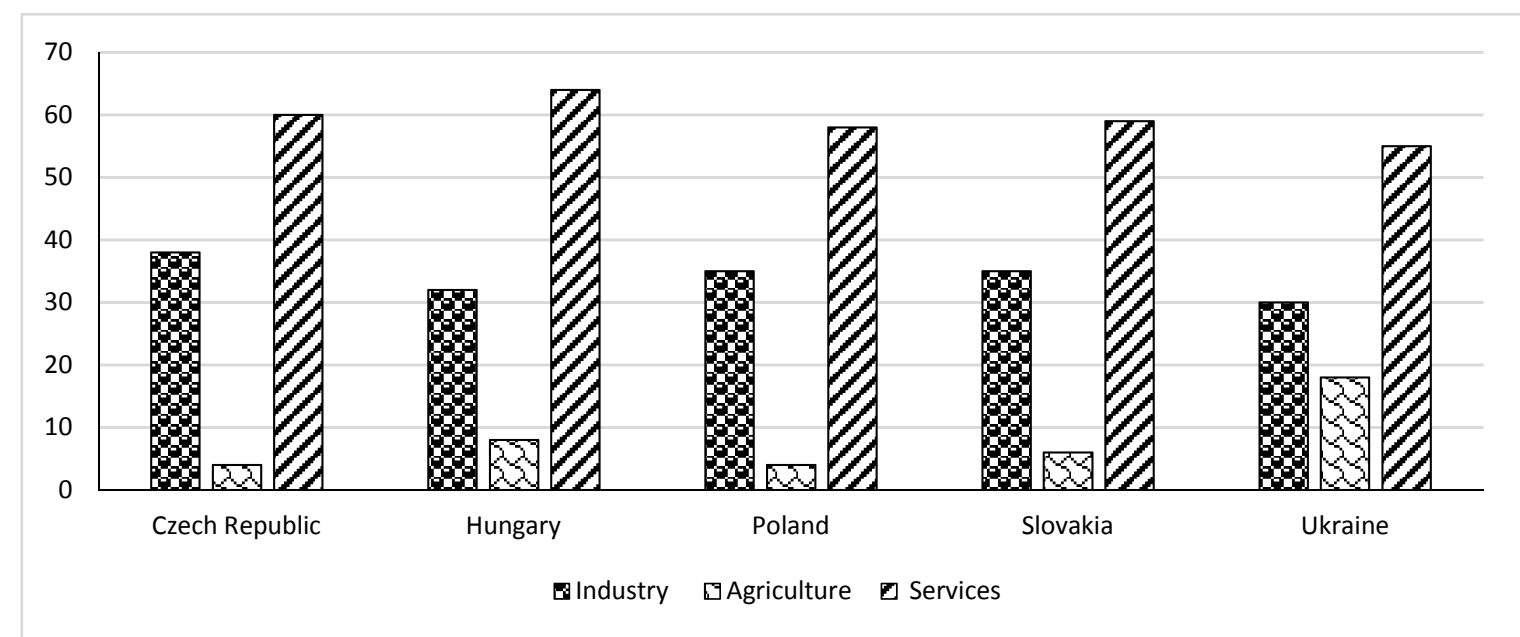

Fig. 5. Sectoral structure of GDP in $2018, \%$

Source: own processing.

According to Fig. 5 shows that the sectoral structure of the Ukrainian economy is far from the European one, which is a significant factor limiting the growth of human potential for a country surrounded by more economically attractive countries.
It should be emphasized that per capita income indicators and also that wages depend not only on the output of the GDP, but also on the employment of the population on the unemployment, nature and structure of the labor force. However, in recent years the number of 
working force in Poland has stabilized by 18.2-18.4 million people in Poland. However, Ukraine continues to lose human resources - in 2012-2018, the number of labor force decreased by 1 million to 20.5 million, including through migration to Poland.

According to the Law of the Ouken, the increase in unemployment (employment reduction) is a significant factor in the deterioration of the ecological dynamics, the decrease of the ecological growth rate. However, it should be acknowledged that this relationship is not significant for Poland and Ukraine, since the real GDP growth rate is «indifferent» to the unemployment rate. A major factor in breaking such links is the high rates of transformation processes, significant structural changes.

An important part of the formation and strengthening of human potential is the employment of labor. It is believed that sustainable economic dynamics provide a proper demand for labor, increase employment (reduce unemployment), and therefore improve wages and gains. At the same time, an effective employment policy adds to the economic policy in general by establishing positive links between good and employment, resulting in better quality human potential.

In Poland, as well as in the EU as a whole, over $80 \%$ of the labor force is a wage earner, and to a considerable extent also forms the cost structure for human resources. This is due both to the structure of ecology and to the high level of social support of the population (special protection, proper education, primary health care).

Like Ukraine, which is also characterized by high expenditures on social programs, their share in the GDP structure remains at the level of Poland. However, public expenditures in 2018 amounted to: UAH 177.8 billion for education, social protection - UAH 145.5 billion, pensions - UAH 140.2 billion (approximately 16\% of GDP).

Usually, such a level of social spending in Ukraine is extremely difficult to support and, probably, in the coming years it is necessary to bring the needs of the population to the payment of the state.

Another important feature of the country's unemployment pattern is youth unemployment (Table 2).

Total unemployment and youth unemployment for 2004-2018

\begin{tabular}{|c|c|c|c|c|c|c|c|c|c|c|}
\hline \multirow[t]{2}{*}{ Countries } & \multicolumn{5}{|c|}{ Total unemployment rate, $\%$ of labor force } & \multicolumn{5}{|c|}{$\begin{array}{l}\text { Youth unemployment, } \% \text { of labor force aged } \\
15-24 \text { years }\end{array}$} \\
\hline & 2004 & 2008 & 2012 & 2016 & 2018 & 2004 & 2008 & 2012 & 2016 & 2018 \\
\hline Czech Republic & 8,2 & 4,4 & 7,0 & 4,0 & 2,2 & 19,8 & 9,9 & 19,5 & 10,5 & 6,7 \\
\hline Hungary & 5,8 & 7,8 & 11,0 & 5,1 & 3,7 & 14,4 & 19,6 & 28,2 & 12,9 & 10,2 \\
\hline Poland & 19,1 & 7,1 & 10,1 & 6,2 & 3,8 & 39,8 & 17,1 & 26,4 & 17,6 & 11,7 \\
\hline Slovakia & 18,6 & 9,5 & 14,0 & 9,7 & 6,5 & 32,9 & 19,1 & 34,0 & 22,2 & 14,9 \\
\hline Ukraine & 8,6 & 6,4 & 7,5 & 9,2 & 8,1 & 15,7 & 14,0 & 17,1 & 22,0 & 17,9 \\
\hline
\end{tabular}

Source: own processing.

High levels of youth unemployment (potentially a high-productivity labour force) in Poland and Ukraine have at least two immediate consequences: an increase in temporary or short-term employment and emigration flows due to the presence of a close economically stronger neighbour. In Ukraine, the migration flow of domestic workers, especially young people, in Poland, in Poland-in Germany, France, the UK.

Employment depends to a large extent on the supply of labor, its quality, as well as the level of cost recovery of labor. In developed countries, there is generally a pattern: higher education - higher qualifications - higher demand for redundant workers - better career opportunities - higher wages.

In the crisis period (2000-2008), during the expansion of global markets and the global demand for goods and services, Poland significantly improved its employment indicators, significantly reducing the unemployment rate. In the crisis and the first post-crisis years (2009-2012), the slowdown of the European economy has led to a decline in aggregate demand, resulting in an increase in unemployment. In Poland, in recent years, a stable positive dynamics of the economy has been re- stored, and the tendency to reduce unemployment has recovered.

With regard to Ukraine, the unemployment rate of workers with secondary education is low, and for workers with higher education - the unemployment indicator is the worst (Fig. 6).

The forecasts regarding the demographic component of human development of Ukraine are not comforting either. According to UNDP forecasts, Ukraine's population will decline sharply. Thus, as of February 1, 2019 , the total population of the country was 42153.2 thousand people. By 2030, UNDP experts estimate that it will be reduced to 40.5 million people, which is a major feature of the current anthropocrisis.

Compared to other countries of the post-Soviet space, in terms of life expectancy, Ukraine holds the highest position - in 2018, life expectancy in Ukraine is 72.1 years. Among Ukraine's neighbors, Poland ranked 40th in the ranking of the healthiest countries, Belarus ranked 81, Moldova ranked 87, and Russia ranked 95.

In general, UNDP experts have determined that the average in our country is to spend 15 years and the average -11.3 years. 


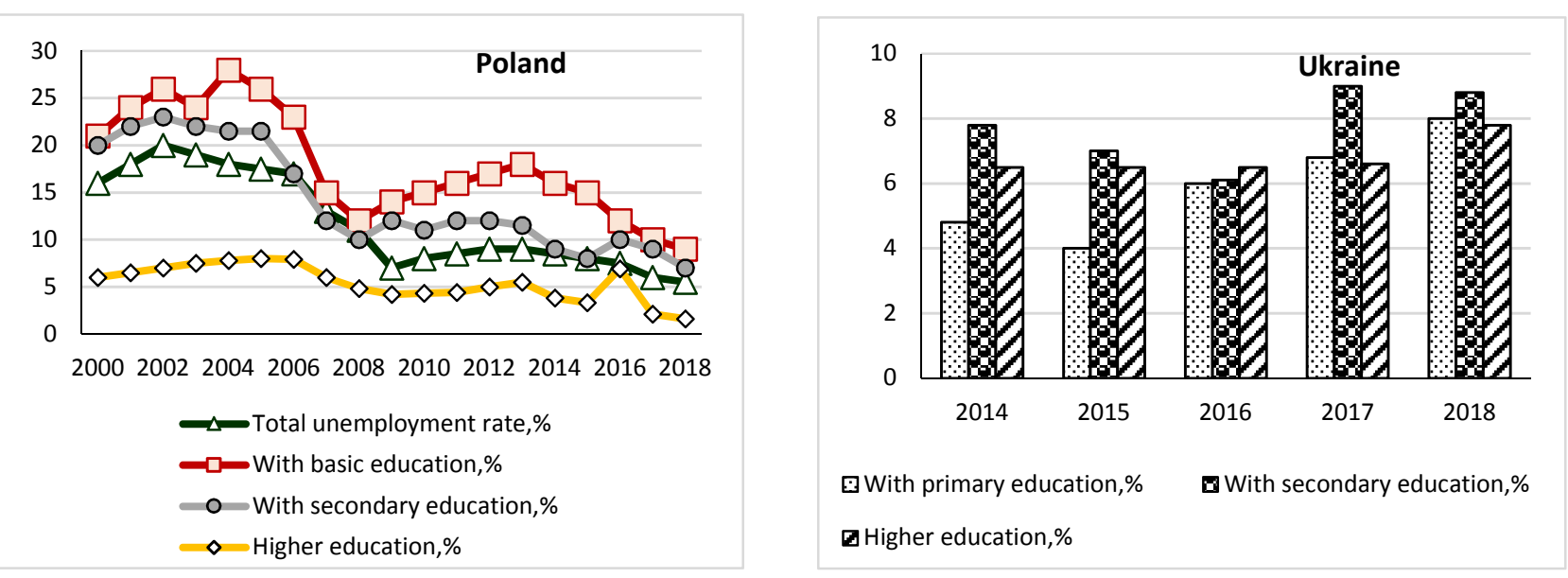

Fig. 6. The dynamics of the unemployed by educational level in Poland and Ukraine in 2000-2018, \% compared to the previous year

Source: own processing.

The expansion of external relations and the acceleration of integration processes indicate the formation of «supporting» factors influencing the ecological structure of individual countries, including. in terms of employment or unemployment.

The expansion of globalization, the flow of investment and the re-qualification of labor provide additional opportunities for improving the quality of human potential.

If the displacement of labor due to the expansion of trade takes place, trade itself becomes a factor in improving the labor system and its (labor) productivity, creating new jobs (Fig. 7).
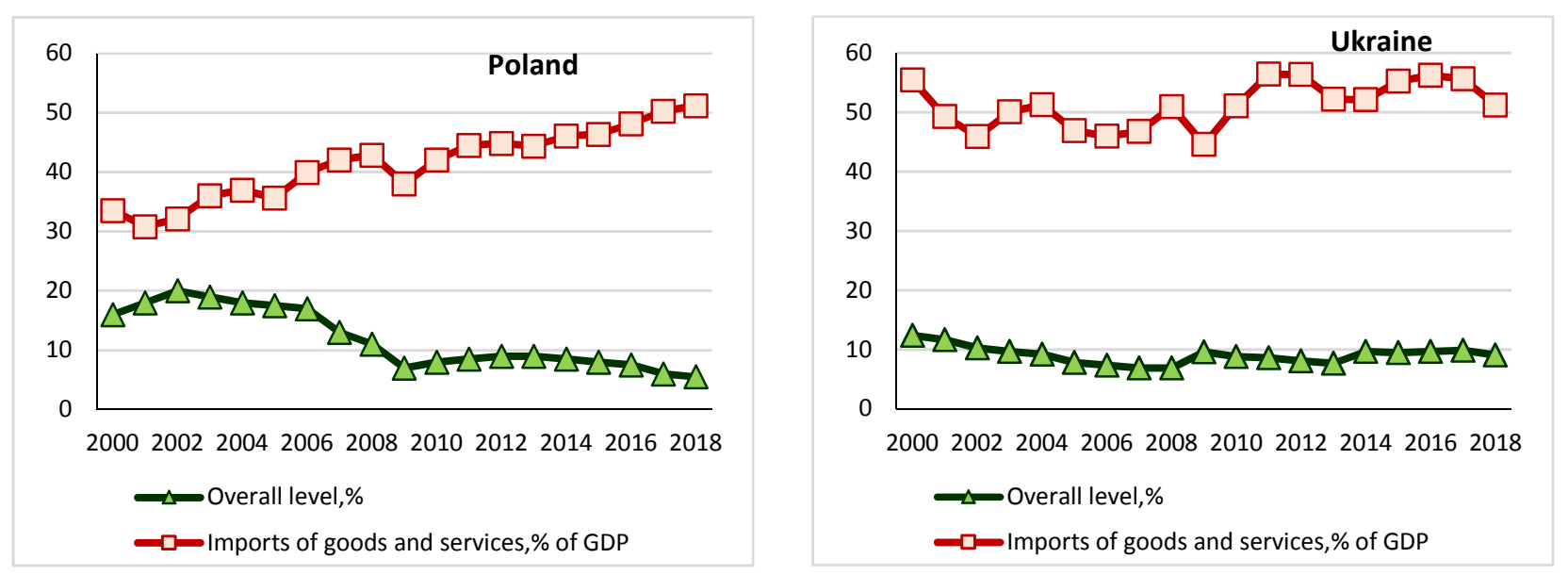

Fig. 7. Dynamics of the unemployed and imports of goods and services in Poland and Ukraine in 2000-2018, \%

Source: own processing.

Today, the stable macroeconomic environment, even in the conditions of increasing imports, «relies» on the growth of unemployment. This applies primarily to European countries. Now in Poland there is a steady improvement in the employment situation, namely the reduction of unemployment, which leads to the stimulation of domestic demand, and thus imports, but this improved the welfare of the population and expanded the resource base of the national economy, and did not lead to the displacement of the national labor force in economic activity. In the case of Ukraine, the trends of imports and unemployment have quite a classic relation- ship, that is, the expansion of imports provokes trends to increase unemployment.

The explanation lies in the fact that in Ukraine (with a low competitive structure of the economy) the traditional is a high propensity to import. This could be offset if the country were sufficiently involved in value chains. However, while such attraction is extremely weak, and therefore the labor market is sensitive to negative changes in the external environment. In fact, we are talking about the fact that Ukrainians, preferring imports, reduce the demand for domestic goods, wash away the components of added value and human potential. 
The promotion of quality jobs can only be adequately secured in dynamic balanced economics, in which investment and infrastructure projects are targeted not only at national economics but also at integrating potentials to enhance their potential.

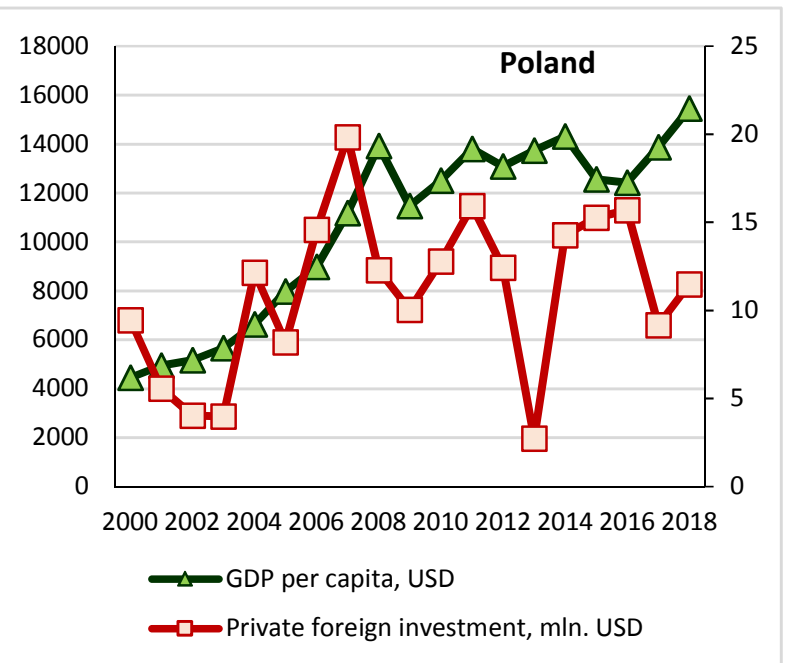

The dynamics of investment in the economy of Poland and Ukraine for the years $200-2018$ is shown in Fig. 8.

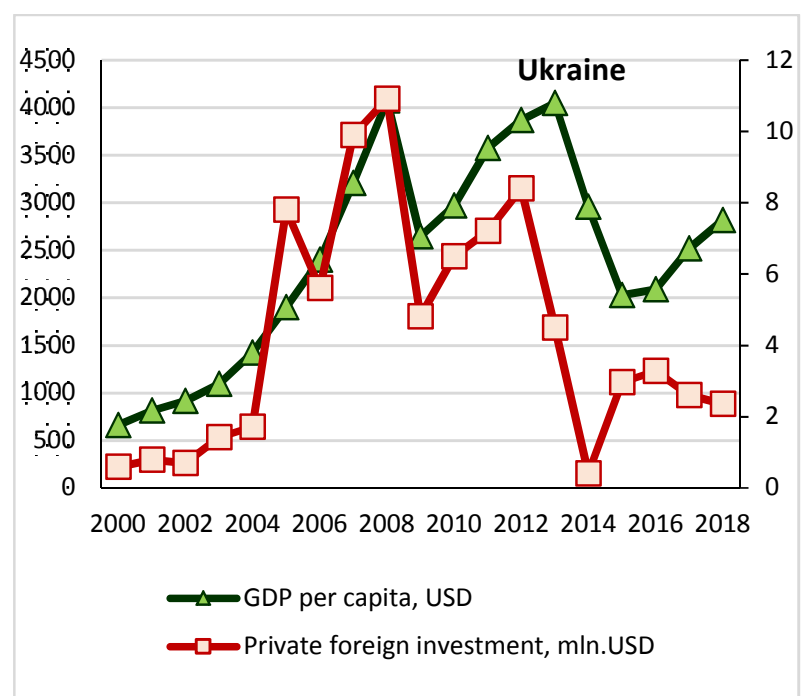

Fig. 8. GDP per capita dynamics and foreign direct investment in Poland and Ukraine in 2000-2018

Source: own processing.

However, the desirable «backlinks» are not always the right thing to do, confirming the appeals to the selected countries. However, in Poland the high growth rate of FDI in the first half of the 2000s, when active integration with the EU took place. It was accompanied by a significant increase in per capita production. However, in recent years, it is preferable to lead the way in stabilizing both GDP and FDI volumes.

Ukraine has a «worsened» scenario of European interconnection - after economically growing and investing in a crisis period, there is a significant reduction in the output of per capita people. In this way, not only has the dynamics of FDI inflows deteriorated in Ukraine, but also the indicators of income have decreased.

Conclusions and perspectives of further research. Brief analysis of macroeconomic components and interrelations with the human potential indicators of Ukraine and Poland, that Ukraine demonstrates a number of statistical indicators and trends inherent in some factors in European countries.

Today, per capita GDP and productivity in Ukraine are significantly lower than those of Poland. Poland is demonstrating a fairly stable positive dynamic. However, in the post-crisis period, Ukraine has significantly worsened its indicators of domestic product production and does not appear to be at the expense of any resources, which may result in a sustained trend of growth.

Ukraine is characterized by high expenditures on social programs. However, while their share in the GDP structure remains at the level of Poland, it is in absolute terms that it complicates the achievement of European standards of quality of life.

Ukraine stands out from the characteristics of unemployment. The peculiarity of Ukraine is that the overall dynamics of unemployment is close to that of Poland. In Ukraine, «deforced» unemployment in the world.

Import growth affects employment opportunities and therefore is a factor of higher unemployment, reduced income, loss of human potential, however in practice many countries there is the opposite - the spread of globalization, the flow of investment and requalification of the labour force to provide additional workers to access new jobs, and increased trade accelerated the formation of new system of labor, creating new jobs, improving productivity.

\section{Literature}

1. Europa 2020. A strategy for smart, sustainable and inclusive growth. - Communication from the Commission, Brussels. 3 March 2010. URL: http://eur-lex.europa.eu/legal- content/EN/TXT/PDF/?uri=CELEX:52010DC2020

$\&$ from $=$ EN. 2. Innovation Union. Aims of the Innovation Union, state of progress and related policy. European Commission. URL: https:/ec.europa.eu/info/research-and-innovation/strategy/goals-research-and-innovation-policy/ innovationunion_en. 3. New Skills Agenda for Europe. Employment. Social Affaire and Inclusion. European Commission. URL: http://ec.europa.eu/social/main.jsp? catId=1223. 4. EU Youth Strategy. European Commission. URL: https://ec.europa.eu/youth/policy/youth-strategy_ en. 5. The European platform against poverty and social exclusion. Commission for Economic Policy. URL: 
http://pes.cor.europa.eu/european-platform-against-poverty-and-social-exclusion. 6. Указ Президента України «Про Стратегію сталого розвитку «Україна - 2020». № 5 від 12 січня 2015p. URL: http:// www.president.gov.ua/documents/18688.html. 7. Економічна та Соціальна Рада ОOH. URL: https://www.un.org/ecosoc/. 8. Середньостроковий план пріоритетних дій Уряду до 2020p., затверджений Розпорядженням КМУ №275 від 3 квітня 2017p. URL: http://zakon2.rada.gov.ua/laws/ show/275-2017-\%D1\%80\#n13. 9. Офіційний сайт ЮНКТАД. URL: https://unctadstat.unctad.org. 10. Офіційний сайт ILO. URL: https://ilostat.ilo.org/data/.

\section{References}

1. Europa 2020. A strategy for smart, sustainable and inclusive growth. - Communication from the Commission, Brussels, 3 March 2010. Retrieved from http://eur-lex.europa.eu/legal-content/EN/TXT/PDF/?uri=CELEX:52010 D C2020\&from=EN [in English].

2 Innovation Union. Aims of the Innovation Union, state of progress and related policy. European Commission. Retrieved from https://ec.europa.eu/info/researchand-innovation/strategy/goals-research-and-innovationpolicy/innovationunion en [in English].

3. New Skills Agenda for Europe. Employment. Social Affaire and Inclusion - European Commission. Retrieved from http://ec.europa.eu/social/main.jsp?catId= 1223 [in English].

4. EU Youth Strategy. European Commission. Retrieved from https://ec.europa.eu/youth/policy/youth-strategy_en_[in English].

5. The European platform against poverty and social exclusion. Commission for Economic Policy. Retrieved from http://pes.cor.europa.eu/european-platform-againstpoverty-and-social-exclusion [in English].

6. Ukaz Prezy`denta Ukrayiny» «Pro Strategiyu stalogo rozvy` tku «Ukrayina - 2020» [Presidential Decree "On Sustainable Development Strategy" Ukraine 2020"] No. 5 of January 12. 2015. President.gov.ua. Retrieved from http:// www.president.gov.ua/documents/18688.html [in Ukrainian].

7. UN Economic and Social Council. Un.org.ecosoc. Retrieved from https://www.un.org/ecosoc/ [in English].

8. Ceredn`ostrokovy`j plan priory`tetny`x dij Uryadu do 2020r. [The Government's mid-term priority action plan for 2020] approved by CMU Ordinance No. 275 of April 3, 2017. Zakon2.rada.gov.ua. Retrieved from http://zakon2.rada.gov.ua/laws/show/275-2017-\%D1\%80\#n13_[in Ukrainian].

9. Official site of UNCTAD. Unctadstat.unctad.org. Retrieved from https://unctadstat.unctad.org [in English].

10. Official site of ILO. Ilostat.ilo.org. Retrieved from https://ilostat.ilo.org/data/ [in English].

Томчук О. Розвиток людського потенціалу України в контексті польського досвіду

У статті досліджено фактори впливу на якість людського потенціалу та виявлені закономірності розвитку потенціалу. У результаті дослідження було вияв- лено, що концепція сталого розвитку, покладена в основу моделі розвитку і ЄС, і України, наголошує, що економічне зростання та розвиток людського потенціалу є взаємодоповнюваними факторами. Проаналізовано динаміку макроекономічних показників України та Польщі. Встановлено, що якість людського потенціалу знаходиться у взаємозв'язку з: ВВП на душу населення, реальною зарплатою, безробіттям, імпортом товарів та послуг та інвестиціями. За результатами дослідження дійшли до висновків, що проаналізовані чинники в більшості здійснюють негативний вплив на якість людського потенціалу України. Перспективою подальших досліджень $є$ обгрунтування моделювання якості людського потенціалу.

Ключові слова: людський потенціал, сталий розвиток, безробіття, зайнятість, інвестиції.

Tomchuk O. Development of the Human Potential of Ukraine in the Context of the Polish Experience

The factors of influence on quality of human potential are investigated in the article and regularities of potential development are revealed. The study found that the concept of sustainable development is embedded in the model of development of the EU and Ukraine, and emphasizes that ecological growth and development of human potential are complementary factors. The dynamics of macroeconomic indicators of Ukraine and Poland is analyzed. The quality of human potential is found to be correlated with: GDP per capita, real wages, unemployment, imports of goods and services and investments. The results of the study concluded that the analyzed factors in the majority have a negative impact on the quality of human potential of Ukraine. Prospects for further research are justification for modeling the quality of human potential.

Keywords: human potential, sustainable development, unemployment, employment, investment.

Томчук О. Развитие человеческого потенциала Украины в контексте польского опыта

В статье исследованы факторы влияния на качество человеческого потенциала и выявлены закономерности развития потенциала. В результате исследования было выявлено, что концепция устойчивого развития, положенная в основу модели развития ЕС и Украины, отмечает, что экономический рост и развитие человеческого потенциала являются взаимодополняемыми факторами. Проанализирована динамика макроэкономических показателей Украины и Польши. Определено, что качество человеческого потенциала находится во взаимосвязи с: ВВП на душу населения, реальной зарплатой, безработицей, импортом товаров и услуг и инвестициями. По результатам исследования пришли к выводу, что проанализированные факторы в большинстве оказывают негативное влияние на качество человеческого потенциала Украины. Перспективой дальнейших исследований является обоснование моделирования качества человеческого потенциала.

Ключевые слова: человеческий потенциал, устойчивое развитие, безработица, занятость, инвестиции.

Received by the editors: 09.12.2019

and final form 19.12.2019 